\title{
the politics of androgyny in Japan: sexuality and subversion in the theater and beyond
}

JENNIFER ROBERTSON-University of Michigan

\begin{abstract}
"Androgyny," as I employ the term here, refers not to a physiological condition (that is, an intersexed body) but to a "surface politics of the body" (Butler 1990:136). Androgyny involves the scrambling of gender markers-clothes, gestures, speech patterns, and so on-in a way that both undermines the stability of a sex-gender system premised on a male-female dichotomy and retains that dichotomy by either juxtaposing or blending its elements. My emphasis on the constructed and performative aspects of gender, and on its distinction from sex, is more than just a theoretical premise or literary exercise; these aspects are outstandingly evident in the two theaters-Kabuki, an all-male theater, and the Takarazuka Revue, an all-female theaterwhich are the main sites of my investigation into the politics of androgyny in Japan. Because so much has been written on the Kabuki theater and so little on the Takarazuka Revue, and because I am interested here in a female-embodied androgyny, I will devote most of my attention to the Revue-its actors, audience, and critics - and particularly to its early history.

I begin by summarizing the spectrum of English and Japanese terms for and usages of androgyny and, in this connection, review the differences between sex, gender, and sexuality. I then move on to my main project, which, after an introduction to the Takarazuka Revue, is to explore some of the ways in which androgyny has been deployed to both support and subvert dominant representations of women and men in Japan. Over the past three centuries the referent of androgyny has changed from male to female. Androgyny has been evoked in variously sited discourses to camouflage "unconventional" sexual practices, creating the illusion of an asexual-in effect, a disembodied-identity. Androgyny has also been used to describe Takarazuka actors who perform both "female" and "male" gender roles without being constrained by either.

How is a dominant gender ideology constructed, reproduced, resisted, and even subverted, sometimes simultaneously, by females and males whose private and professional lives confound tidy, universalistic schemata, whether of literary or of theoretical origin? Real people tend to be messy, inconsistent, hypocritical, and mostly opaque when the relations between sex, gender, and sexuality are at issue. Thus, I examine debates and differences among the Revue's
\end{abstract}

The gendered body is constructed and performative. Androgyny involves the scrambling of gender markers (clothes, gestures, speech patterns) in a "surface politics of the body." I explore the politics of androgyny in Japan as they have been embodied and enacted by same-sex theater actors and expressed in Japanese society at large. The referent of androgyny, or the body of the androgyne, has changed over the past 300 years from male to female. Since the early 20th century, androgyny has been deployed in both dominant and marginal discourses to camouflage "unconventional" female sexual choices and practices by creating the illusion of an asexual identity. It has also been evoked in reference to females who "do" both "female" and "male" gender without being constrained by either. [androgyny, gender, sexuality, theater, girls and women, Japan] 
directors, performers, and fans, the mass media, and the state ${ }^{1}$ about the significance and symbolism of the Takarazuka Revue. Moreover, the stereotype of the Japanese as a homogeneous people has had the extended effect of whitewashing a colorful variety of gender identities and sexual practices. It is my general impression that more often than not the differing experiences of female and male members of Japanese society have been insufficiently problematized and have been confused with dominant, naturalized gender ideals (for example, housewife and workaholic) and the behavior of fictive characters. This article should help to dismantle some of the more tenacious stereotypes of Japanese women and men and to provoke discussion on the complicated relations between sex, gender, and sexuality in Japan and elsewhere.

\section{words and usages}

Since the mid-1980s the English loanword andorojenii (androgyny) has appeared frequently in the Japanese mass media and elsewhere in reference to clothing fashions, including "crossdressing," an expression most often used in reference to men's clothing adapted by and for women (Asahi Shinbun, 3 December 1984; Asano 1989; Yagi 1989). Since andorojenii is a transliteration, the term is often simultaneously defined in Japanese as either ryōsei (both sexes/ genders) or chūsei (between sexes/genders). ${ }^{2}$ In English, following ancient Greek usage, "androgyny" literally means "male-female," although what the word signifies and represents is far from literal. Heilbrun, for example, presents androgyny — which she defines as the realization of man in woman and woman in man-as an ideal, nonpolarized way of being necessary for the survival of human society (1982 [1964]:xx). Rich, on the other hand, argues that the very structure of the word androgyny "replicates the sexual dichotomy and the priority of andros (male) over gyne (female)" (1976:76-77).

Japanese scholars have taken similar theoretical and political positions. Asano, for example, adopts Jung's quasi-biological theory of androgyny ${ }^{3}$ in exploring the idea of androgyny as it has been expressed in Japanese popular religious texts (1989). She bemoans the progressive loss of "traditional" androgyny (qua "the harmony of 'male' and 'female' qualities") over the course of Japan's modernization but observes a revival of androgyny (qua "cross-dressing") in the present (1989:201-202). Similarly, Akiyama evokes Jung's theory of the "inherent androgyny" of all people to debunk the notion of "sexual perversion" (seitōsaku), insisting that the sexual choices available to women and men are as varied as the combinations of feminine and masculine tendencies they embody (Akiyama 1990; see also Ifukube 1932). And Kurahashi Yukiko suggests the corporeality of Jung's "animus," or "male archetypical essence," in her neologism for "a female who wants to be a man": penisuto, or "penist" (cited in Hyūga 1971:26). Yagi, on the other hand, like Rich, dismisses androgyny as an idea (and ideal) that suppresses women's sexual difference in the name of equality (1989).

Medical-anatomical and psychological-descriptions and interpretations of androgyny were especially plentiful in early 20th-century Japan. The works of Euro-American sexologists-Freud, Jung, Krafft-Ebing, Ellis, Carpenter, Hirschfeld-were exported directly to Japan, where they were studied, translated, adapted, and augmented by Japanese sexologists (Hanafusa 1930; Ifukube 1932; Ōsaka Mainichi, 31 January 1935; Ōzumi 1931; Yasuda 1935). Physiological androgyny, or an intersexed body, was of special interest at that time to scholars of forensic medicine, who addressed the phenomenon in terms of conscription, patrilineality (specifically family name and inheritance), political service, and civil rights, all of which were contingent upon the establishment of a person's body as male-sexed (for example, Takada 1926 [1917]:285-291).

A brief discussion of the relationship between sex, gender, and sexuality is called for at this juncture. Regardless of their popular conflation, the three are different. "Sex," as I use it here, refers to the physical body distinguished by either female or male genitalia—or, in the case of 
intersexed persons, both, to varying degrees-and their usual capabilities, such as menstruation, seminal ejaculation, and orgasm. (Thus, when I use the term "female body," I am referring to a female-sexed body.) "Gender" refers to sociocultural and historical conventions of deportment, costume, gesture, and so on, attributed and ascribed to female- and male-sexed bodies. "Sexuality" may overlap with sex and gender, but refers to a domain of desire and erotic pleasure more complex and varied than the hegemonic construction of reproductive heterosexuality would have it (see Kessler and McKenna 1985 [1978]:1-12; Vance 1985:9).

Sex, gender, and sexuality may be related, but they are not the same thing; the pattern of their articulation is negotiable and negotiated constantly. Although the three may be popularly perceived as irreducibly joined, their alignment remains a situational and not a permanently fixed condition. In the words of Butler-whose recent book problematizes the "Western" belief in the vertical alignment of sex, gender, and sexuality (namely, female-feminine-heterosexual)_- "man and masculine might just as easily signify a female body as a male one, and woman and feminine a male body as easily as a female one" (Butler 1990:6).

Among Japanese feminists and scholars influenced by feminist theory, sex and gender and sexuality have been distinguished in principle since about 1970 (Yuri 1985). In Japanese, linguistic distinctions between sex and gender are created by suffixes. Generally speaking, sei is used to denote sex-and seisei to denote sexuality (literally, the sex of sex)—as in josei for female and dansei for male. Since the dan in dansei can refer both to male sex and to "male" gender, the suffix sei, with its allusions to fundamental parts (for example, genitalia), is necessary in order to specifically denote sex. Gender is denoted by the suffix rashii, with its allusion to appearance or likeness (Fukutomi 1985; Kōjien 1978a, 1978b). A "female"-gendered person is onnarashii, a "male" -gendered person, otokorashii. ${ }^{4}$ The emphasis here is on a person's proximity to a gender stereotype. When attention is to be drawn to an individual's resemblance to a particular female or male, the term often used is joseiteki (like a/that female) or danseiteki (like a/that male). That an individual resembles a particular female or male in the first place is precisely because both parties approximate a more generic gender stereotype. The difference between onnarashii or otokorashii and joseiteki or danseiteki is significant, although the two terms are often used interchangeably in popular parlance. Further complicating matters is the use of the terms onna and otoko to refer to both sex and gender, the distinction being evident only in the context used.

Two of the most frequently encountered Japanese terms referring to androgyny are ryōsei and chūsei, which were coined in the early 20th century when they first appeared in journal and newspaper articles on homosexuality and "abnormal sexual desire" (Kabeshima, Hida, and Yonekawa 1984:185). Ryōsei was and is most generally used to refer either to someone with both female and male genitalia or to someone with both feminine and masculine characteristics. Consequently, ryōsei has been used to refer to intersexed bodies (see Hyūga 1971; Komine and Minami 1985:57, 296-301) as well as to persons who behave as if they were at once masculine and feminine. The latter combine and embody the stereotyped and otherwise polarized and mutually exclusive characteristics attributed to females and males (see Akiyama 1990; Asano 1989; Ifukube 1932; Komine and Minami 1985:57).

Chūsei, on the other hand, has been used to mean "neutral" or "in between," and thus neither woman nor man. Whereas ryōsei emphasizes the juxtaposition or blending of either sex or gender differences, chūsei emphasizes erasure or nullification of differences. A person whose body is intersexed usually is raised or passes as one or the other sex/gender (see Sawada 1921; Komine and Minami 1985:296-301). A "neutral" body, on the other hand, is one whose surface appearance (costume, hairstyle, intonations, speech patterns, gestures, movements, deportment, and so on) confounds the conventional alignment of sex with gender and scrambles received gender markers. The normalizing principle at work here posits that, say, masculinity is a "natural" attribute of male-sexed bodies. However, "masculinity" is not a product of nature-that is, some sort of agentless creation-but a sociohistorical representation of male- 
sexed bodies, a representation that is subject to manipulation and change. Gender, in other words, names an unstable "amalgam of signifiers" (Pacteau 1986:80). Despite the workings of this normalizing principle, it remains the case that in Japan, as attested in part by Kabuki and Takarazuka, neither femininity nor masculinity has been deemed the exclusive province of either female or male bodies.

During the early Edo (or Tokugawa) period (1603-1868), androgyny was embodied by the onnagata, the Kabuki theater actor specializing in girls' and women's roles. From the 1910s to the present, generally speaking, androgyny has been embodied by the otokoyaku, the Takarazuka Revue actor specializing in boys' and men's roles. Watanabe attributes the disappearance of male-embodied androgyny to the "de-eroticisation of the male body" resulting from the modernization of political and social institutions toward the end of the 19th century, when the xenophobic Tokugawa Shogunate was overthrown by imperialists and a new civil code was drawn up on the Prussian model (Watanabe and Iwata 1989 [1987]:130). Further contextualizing Watanabe's hypothesis, I propose that the "de-eroticisation of the male body" paralleled the emergence at this time of a "woman problem," part of which involved contradictory and contested images of and roles for Japanese women. Significantly, the Takarazuka Revue, founded in 1913, was among the modern theaters marking the return of females to a major public stage after they were banned from the Kabuki theater by the Shogunate in 1629. ${ }^{5}$ Moreover, in the early 20th century - as to a significant extent today - the Takarazuka Revue was the focus of heated debates about the construction and performance of gender. A brief introduction to the Takarazuka Revue and its actors follows.

\section{the Takarazuka Revue}

The all-female Takarazuka Revue (Takarazuka Kagekidan) was founded in the hot springs resort of Takarazuka by Kobayashi Ichizō (1873-1957), the Hankyū railroad-and-department store tycoon. ${ }^{6}$ Today, with two huge theaters in Takarazuka and Tokyo and regularly scheduled regional and international tours, not to mention television and radio broadcasts, the Revue remains one of the most widely recognized and watched of the so-called theaters for the masses (taishū engeki) that were created in the early 20th century (see Robertson 1991b). Takarazuka productions range from Japanese historical dramas, such as the Tale of Genji, to Western musicals, such as Oklahoma. The widespread popularity and social impact of the Revue are evident in the literally hundreds of articles that have been published in a wide range of print media since its founding. In fact, this article was inspired in part by the many early articles linking the establishment of the Takarazuka Revue to the problematic emergence of "androgynous" females and the diagnosis in women of a newly coined affliction, "abnormal sexual desire" (hentai seiyoku).

The Revue's actors are called "Takarasiennes" (takarajiennu), after Parisiennes, in recognition of the original influence of the French revue. They include otokoyaku, the "male" gender specialists, and musumeyaku, the "female" gender specialists. Upon their successful application to the Takarazuka Music Academy, founded in 1919 as a part of the Revue complex, the student actors are assigned (what I call) their "secondary" genders. Unlike "primary" gender, which is assigned at birth on the basis of an infant's genitalia, secondary gender is based on both physical (but not genital) and sociopsychological criteria: height, physique, facial shape, voice, personality, and, to a certain extent, personal preference. Secondary gender attributes or markers are premised on contrastive gender stereotypes themselves; for example, men are supposed to be taller than women; to have a more rectangular face, thicker eyebrows, a higherbridged nose, darker skin, straighter shoulders, narrower hips, and a lower voice than women; and to exude charisma (kosei), which is disparaged in women. The assignment of gender involves the selection and cosmetic exaggeration of purported (nongenital) physical differences 
between females and males, and it reinforces socially prescribed behavioral differences between women and men. Ironically, in the Takarazuka Revue, gender(ed) differences that are popularly perceived as inherent in female and male bodies are embodied by females alone.

The femininity embodied and enacted by the musumeyaku serves as a foil for the masculinity of the otokoyaku. ${ }^{7}$ Much of the training of the Revue actors involves learning a vocabulary of gendered gestures, movements, intonations, speech patterns, and the like. An otokoyaku, for example, must stride forthrightly across the stage, her arms held stiffly away from her body, her fingers curled around her thumbs. In contrast, a musumeyaku pivots her forearms from the elbows, which are kept pinned against her side, constraining her freedom of movement and consequently making her appear more "feminine." In keeping with the patriarchal values informing the Takarazuka Revue, musumeyaku have represented the fictional Woman with little if any connection to the actual experiences of females. The otokoyaku, however, have been actively encouraged to study the behavior and actions of men offstage (as well as in films) in order to more effectively idealize men on stage, be they samurai or cowboys. Personal or contrary motivations and desires aside, both musumeyaku and otokoyaku are the products of a masculinist imagination in their official stage roles.

\section{conceptualizing androgyny}

There seems to have been no formal concept of androgyny prior to Yoshizawa Ayame's development of a theory and method for the Kabuki onnagata, or "female" gender specialist, in the early Edo period. Ayame himself (historical figures are often referred to by the given name) was a Kabuki onnagata, and his theory was a twist on the Buddhist concept of henshin, bodily transformation or metamorphosis. Hen is the term for change, in both a transitive and an intransitive sense. Shin (also pronounced $\mathrm{mi}$ ) is the term for body in the most comprehensive sense: that is, a physical, mental, social, historical, and spiritual entity (Gunji 1988; Hattori 1975:31-35; Ichikawa 1985:38-47; Imao 1982:29). The term henshin originally referred to the process whereby deities assumed a human form in order to better promulgate Buddhist teachings among the masses of sentient beings.

Related to henshin is the process of henjo nanshi (also tennyo jōnan), whereby a female body is transformed, or metamorphoses, into a male body. Since female bodies are regarded in orthodox Buddhist doctrine as not only polluted but also marks of a lower form of existence, enlightenment is not possible for them unless they manage to metamorphose into male bodies. The effect is not the creation of an androgyne, but a female's total transformation into "the opposite" sex-in short, rebirth as a male over the course of several generations. It is clear that the orthodox Buddhist concept of henshin refers to physical bodies (including genitalia) and not only to embodied markers of gender. ${ }^{8}$ However, the term henjo nanshi was also used popularly during the Edo period in reference to intersexed bodies. For example, a peasant woman was deemed to be suffering from henjo nanshi sho (the henjo nanshi syndrome) when, at the age of 27, she developed "male genitalia" (Tomioka 1938:104).

Henshin is also central to the Kabuki theater and refers specifically to the received process by which an onnagata becomes Woman, as opposed to impersonating a given woman. Ayame's theory resembles the Buddhist concept of henshin with the exception that gender (and not sex) is involved in an onnagata's transformation from a man to Woman. Ayame conceived of the onnagata not as "a male acting in a role in which he becomes a 'woman'," as "a male who is a 'woman' acting a role." ${ }^{\text {"10 }}$ In other words, the transformation is not part of a particular role but precedes it.

Ayame insisted that an onnagata embody femininity in his daily life. ${ }^{11}$ Simply impersonating a given woman was neither adequate nor appropriate. To clinch his point, Ayame insisted that the construction of Woman not be left up to the idiosyncratic notions of a particular actor. 
Instead, he introduced categories of Woman, each with predetermined characteristics. The role of a "chaste woman" (teijo), for example, was to be based on Onna Daigaku (Greater Learning for Females [1672]), an influential primer on femininity written by a leading (male) Confucian scholar (cf. Imao 1982:147-153). Given the Kabuki theater's ambivalent reception by the Tokugawa Shogunate, coupled with the low, outsider status of actors during the Edo period, the construction and performance of femininity on the basis of Onna Daigaku quite likely added a modicum of legitimacy to the urban theater. ${ }^{12}$

Ayame eschewed what he called the prevailing "androgynous" figure of the onnagata, describing it as futanarihira-literally, "double-bodied" (Imao 1982:145-146; Maeda 1973:750, 867, 884; Takada 1926 [1917]:287). ${ }^{13}$ An androgynous onnagata blurred the boundaries between sex and gender, male and female, femininity and masculinity (Imao 1982:145-147). Ayame's apparent objective in formulating a theory and method for the onnagata was to make distinct both those boundaries and the bounded, all the while recognizing that sex and gender were not "naturally" aligned in any one body.

An onnagata, then, according to Ayame, was not an androgyne but an embodiment of patriarchally inscribed, state-regulated "female" gender. He/she was unequivocally Woman, a model for females offstage to emulate and for males offstage to proposition. Apparently, during Ayame's time there was even "tacit approval" for the onnagata "to bathe at the public baths reserved for women" (Watanabe and Iwata 1989 [1987]:86). From Ayame's point of view, the process of henshin, or transformation, precluded a blending of the two genders. However, because an onnagata was a male-sexed body enacting a type of femininity and thus disturbing the conventional alignment of sex, gender, and sexuality, Watanabe regards the Kabuki actor as an androgyne (Watanabe and Iwata 1989 [1987]:74-135). For Ayame, "female" gender superseded and even negated a male body, and thus the onnagata, having become Woman, could bathe with females at public bathhouses; in Watanabe's view, the "female" gender and male body of the Kabuki actor formed a dialectic. According to Watanabe, the androgyny of the onnagata was achieved by style (coiffure and clothing) in addition to (homo)sexual practices, specifically the taking of a "passive" feminine role.

With the Meiji Restoration of $1868^{14}$ and the modernizing (or westernizing) state's insistence on short hair and Western clothing for men, the "feminine beauty" hitherto ascribed to and achieved by male bodies was transferred to female bodies (Watanabe and Iwata 1989 [1987]:130-133). Watanabe describes the effect of the Meiji state's gender regulations in terms of an "anti-androgyne complex," according to which males were prevented from having any qualities in common with females (Watanabe and Iwata 1989 [1987]:127); that is, they were prevented, by convention, from embodying and performing femininity outside the Kabuki theater. The establishment of the Takarazuka Revue, in contrast, sanctioned the embodiment and performance of masculinity by females. However, henshin was not a process officially prescribed for Takarazuka otokoyaku. Kobayashi, the Revue's founder, was no Ayame, and he was keen on limiting an otokoyaku's appropriation of "male" gender to the Takarazuka stage. Along with many early 20th-century sexologists, he believed that a masculine female outside the context of the Revue was something abnormal and perverted.

Kobayashi proclaimed that "the [Takarazuka] otokoyaku is not male but is more suave, more affectionate, more courageous, more charming, more handsome, and more fascinating than a real male" (Kobayashi 1960:38). But, although her body served as the main vehicle for the representation and enactment of masculinity, an otokoyaku, according to Kobayashi, was not to become unequivocally Man, much less a model for males offstage to emulate. Whereas the g[k]ata in onnagata means model or archetype, the yaku in otokoyaku connotes the serviceability and dutifulness of a role-player: "The Takarazuka otokoyaku affects a 'male' guise, while the [Kabuki] onnagata . . . is completely transformed into a 'female.' As the term otokoyaku attests, the female who plays a man is but performing a duty" (Nōzaka Akiyuki, cited in Tanabe and Sasaki 1983:130). Thus, Revue directors refer to the actor's achievement of "male" gender 
not in terms of transformation or metamorphosis (henshin) but in terms of "putting something on the body" (mi ni tsukeru)_-in this case, markers of masculinity.

Kobayashi viewed the theater as one of the most powerful means of influence. He envisioned the Takarazuka Revue as the cornerstone of the "state theater" movement in the 1930s and 1940s, a movement whose agenda included the portrayal of state-regulated gender roles-particularly that of the "good wife, wise mother" —and an emphasis on the patriarchal, conjugal household (Robertson 1991b). Therefore, it would not do to enhance the exemplariness and semiotic authority of the otokoyaku by stipulating that she also be a man in her daily life.

\section{female sexualities}

I now turn to a review of the discourses of gender and sexuality that informed the social climate in which the Takarazuka Revue was established and received. Any interpretation of the Revue's popularity today must take into account its historical beginnings and unprecedented impact on the status quo. Therefore, as I noted earlier, a substantial part of my description and analysis focuses on developments in the early history of the Revue and in the society at large. Where pertinent, and especially in the last section of this article, I discuss gender and androgyny as performed and constructed in the Revue from the 1960s onward.

It was in the context of state formation and nationalism that the ryōsai kenbo, or "good wife, wise mother," was codified as the model of "female" gender in the patriarchal Meiji Civil Code. ${ }^{15}$ The end of the Tokugawa Shogunate and its 250 -year seclusion policy was marked by the restoration of the emperor to a ruling position, by the promulgation of a European-inspired constitution, and by the international emergence of Japan as a new nation-state. The discourse of sexualities is closely linked to nationalism and state formation (see Corrigan and Sayer 1985; Mosse 1985; Watson 1990). At the same time, the printed word is a key factor in the conceiving of the nation and the promoting of nationalism (Anderson 1983). Many of the dozens of articles on femininity, marriage, sex, gender, sexuality, androgyny, and the revue genre published in the many news and literary journals founded at this time were written from a nativist and nationalist angle. Some of the authors even elaborated on the links between all of these issues (for example, Sugita 1935; Takada 1934). In fact, only decades after the Meiji Restoration, social commentators began to react negatively to what they interpreted as the "masculinizing" effect of westernization on Japanese women (for example, Tachibana 1890). And in 1935 one Japanese sexologist claimed in a newspaper interview that women's interest in adopting men's dress was fostered by the revue theater and foreign films (Hori Kentarō, cited in Ōsaka Mainichi, 31 January 1935). As I have discussed elsewhere, Kobayashi himself recognized the potential of theater, as an agent of the state, to orchestrate the construction and regulation of gender and to stage the enactment of gender roles in society (Robertson 1991b).

Newspaper, magazine, and journal articles published between 1900 and 1945 make it clear that female sexualities, and particularly certain homosexual practices, provoked the most perplexity and made the biggest headlines. The "woman problem" (fujin mondai)- the term for issues related to females' civil rights that were made problematic by Meiji feminists-appeared to be accompanied by problem women. ${ }^{16}$ Before and even after the Meiji period, published writers and critics - the vast majority of whom were male-relegated sexual desire in females to courtesans and prostitutes (see Robertson 1991a). "Ordinary" women were defined by the gender roles of "daughter," "wife," and "daughter-in-law." Motherhood and mothering emerged as additional components of state-regulated sex and gender in the Meiji period (Koyama 1982, 1986; Mitsuda 1985; Nolte and Hastings 1991). Nearly all of the women's journals founded in the first two decades of the 20th century were devoted to promoting, among their hundreds of thousands of readers, the socialization of women as "good wives, wise mothers" (Watashitachi no rekishi o tsuzuru kai 1987). One exception was Seitō (Bluestocking), a fem- 
inist journal founded by Hiratsuka Raichō in 1911 and under surveillance by the government shortly afterward for publishing articles critical of the patriarchal household and family system (Hara 1987:16, 22). The "Taishō Democracy," as the Taishō period (1912-25) is popularly called, was hardly democratic with respect to the condition of women. Not only was the Seitōsha (Bluestocking Society) banned, but under the auspices of the Public Peace Law of 1925, women were banned from congregating in public and from participating in political activity in general.

In the spring of 1938, the now explicitly militarist Shōwa (1926-89) government banned from women's journals any articles related to sex and sexuality that did not trumpet the state's patriarchal values and pronatal policies (Hara 1987:16-21). Not surprisingly, in August 1939 the Osaka prefectural government outlawed otokoyaku_- "the acme of offensiveness" - from public performances in that prefecture (Ōsaka Nichinichi, 20 August 1939). Kobayashi, who from July 1940 to April 1941 served (in the second Konoe cabinet) as Minister of Commerce and Industry, colluded with government censors to produce musicals that exalted the image of the "good wife, wise mother," an image further reified at that time as Nippon fujin, or the "Japanese Woman" (Ōsaka Chōhō, 7 September 1940). Typical of the musicals staged during this period of militarization and state censorship was Illustrious Women of Japan (Nippon meifu den, 1941), a nationalistic extravaganza dedicated to heroines, mothers of heroes, and "women of chastity" (English Mainichi, 22 February 1941). Takarasiennes were also recruited into patriotic women's associations and charged with entertaining farm workers, troops in the field, and the war wounded.

Since becoming a fully adult female involved marriage and motherhood, unmarried girls and women were referred to (during and after the Meiji period) by the term shōjo, which means, literally, a "not-quite-female" female. (Over the past several years, "gal" [gyaru] has emerged as the term for an older, more "female" shōjo. Shōjo now tends to be used in reference to teenage girls, and gyaru to unmarried women in their early twenties. $)^{17}$ Shōjo denotes both females between puberty and marriage and that period of time itself in a female's life (shōjoki) (Kawahara 1921:112; Tamura 1913). Shōjo also implies heterosexual inexperience and homosexual experience, a point to which I will return. (Gyaru, on the other hand, does not imply homosexual experience, but rather conjures up the figure of a self-assertive, self-sufficient woman who cultivates boyfriends.)

The state emphasized universal-if segregated and sexist-education, together with the notion that a brief stint in the burgeoning urban industrial and commercial workforce was a desirable thing for females. This emphasis had the effect of increasing the number of years between puberty and marriage (see Murakami 1983). Kobayashi was among the many influential persons who published articles in women's journals reminding their female readers that working outside the home for wages should be construed not as a career in itself but rather as preparation for marriage (Shida and Yuda 1987:115).

The shōjo category included the "new working woman" (shinshokugyō fujin) and her jaunty counterpart, the "modern girl" (modan gāru, or moga), herself the antithesis of the "good wife, wise mother." The flapper-like moga fancied themselves actors whose stage was the Ginza, at that time Tokyo's premier boulevard. Along with the "new working women," they were Takarazuka fans. Many of the urban-based "new working women" aspired to the Revue stage, and, by the same token, Takarazuka otokoyaku were often referred to in the press as "modern girls," especially after 1932, when the "male" gender specialists began sporting short haircuts (Ōsaka Mainichi, 29 May 1923).

Generally speaking, not only sexism but also ageism was the rule in the workplace. Male employers preferred women up to 24 years of age, and there were few employment opportunities for women over the age of 30. In fact, not many women could afford the financial strain of remaining single; those who did manage to support themselves included doctors, teachers, midwives, nurses, and, to a certain extent, actors (Shida and Yuda 1987:114). Some women, 
in the first half of the 20th century at least, "passed" as men in order to secure employment as rickshaw drivers, construction supervisors and laborers, fishers, department store managers, grocers, and so on (Tomioka 1938:103). ${ }^{18}$ "Passing" was associated with sexual deviancy only in the case of urban upper-middle-class girls and women who, it was argued, wore masculine attire not to secure a livelihood but to flaunt their "moral depravity." As privileged and educated - in short, bourgeois-girls and women, they were supposed to fulfill the state-sanctioned "good wife, wise mother" gender role. Consequently, those who resisted were vilified in journal and newspaper articles on "masculinized" (danseika) females and were roundly criticized in texts and treatises on "female" psychology (Sakabe 1924; Sugita 1929, 1935; Ushijima 1943; Yasuda 1935).

Ironically, given Kobayashi's views on work and marriage, tenure in the Takarazuka Revue further lengthened the shōjo period, and many of the actors continued to perform into their thirties before retiring well beyond the average age of marriage. ${ }^{19}$ Perhaps in response to criticism, the Revue management in 1936 revealed an informal "retirement policy" (teinensei), the first of several, whereby Takarasiennes whose tenure in the Revue exceeded 20 years would be encouraged to retire (Shin Nippō, 17 June 1936). For the most part, however, it continues to be the case that, provided an actor does not marry or leave to pursue other avenues of show business, she can spend her life as a Takarasienne, if not always on stage, then as an instructor or supervisor.

Apart from conceiving of an all-female revue as a commercially viable complement of the all-male Kabuki theater, Kobayashi was interested in producing (through resocialization and retraining) "good wives, wise mothers." In his autobiographical Takarazuka manpitsu (Takarazuka Jottings) and earlier essays, he made clear his antagonism toward the "modern girl" (moga) and masculinized females. Kobayashi theorized that by performing as men, females learned to understand and appreciate males and the masculine psyche. Consequently, when they eventually retired from the stage and married, which Kobayashi urged them to do, they would be better able to perform as "good wives, wise mothers," knowing exactly what their husbands expected of them (Kobayashi 1960:38, 91; Ueda 1974:139). Elsewhere, I have shown how a number of Takarasiennes appropriated their secondary gender in such a way as to resist and subvert Kobayashi's designs: some used their tenure in the Revue as a springboard into the wider world of show business; some sought to present the otokoyaku as an alternative "female" gender role; some did both (Robertson 1989).

Girls' schools, including the Takarazuka Music Academy, and the Revue, along with their (unmarried) female instructors and students, were singled out by sexologists and social critics as the sites and agents of homosexuality among females (see Sugita 1929, 1935; Tamura 1913; Ushijima 1943). ${ }^{20}$ In 1910, one of the first articles on this subject was published in a leading women's newspaper, the Fujo Shinbun (Fukushima 1984 [1935]:561-563). Distinctions were drawn between two types of homosexual relationships between females: dōseiai (same-sex love) and ome no kankei (male-female relations). ${ }^{21}$ It is clear from the article that what the editorial staff meant by "same sex" was actually "same gender" and that ome referred to a "butch-femme" -like couple (that is, same sex, different genders). Characterized as a passionate but supposedly platonic friendship, the dōseiai relationship was regarded as typical among girls and women from all walks of life, but especially among girls' school students and graduates, female educators, female civil servants, and thespians (Fukushima 1984 [1935]:561; see also Tamura 1913; Yasuda 1935). Such relationships were also referred to as " $\mathrm{S}$ " or "Class S" (kurasu esu), with the " $\mathrm{S}$ " standing for sister, shōjo, sex, or all three combined. Class $\mathrm{S}$ continues to conjure up the image of two schoolgirls, often a junior-senior pair, with a crush on each other (Miyasako 1986:61).

Ome relationships, on the other hand, were described as

a strange phenomenon difficult to diagnose on the basis of modern psychology and physiology. ${ }^{22}$. . One of the couple has malelike [danseiteki] characteristics and dominates the [femalelike] other. ... 
Unlike the [dōseiai couple], friends whose spiritual bond has taken a passionate turn, the latter have developed a strange, carnal relationship [niku no sesshoku] . . . stemming from their carnal depravity [nikuteki daraku]. . . . The malelike female is technically proficient at manipulating women. . . . Doctors have yet to put their hoes to this uncultivated land [mikaikonchi]. [Fukushima 1984 (1935):562]

This article and others like it (for example, Tamura 1913; Yasuda 1935) make it clear that even an overheated dōseiai (that is, homogender) relationship was not pathological in the way that an ome (that is, heterogender) relationship was, the latter being not only explicitly sexual but also a heretical refraction of the heterosexual norm codified in the Meiji Civil Code. The most objective writers, not surprisingly, referred to an ome couple as füfu (husband and wife), a marital metaphor that safely contained (and in effect neutralized) the sexual difference represented and practiced by the two females.

The Fujo Shinbun article introduced recent "medical" findings in surmising that females were more prone than males to homosexuality. It was postulated that the "natural" passivity (muteikōshugi) of females made them susceptible to neurasthenia (shinkeishitsu), which in turn occasioned a pessimism expressed in the form of homosexuality. ${ }^{23}$ Ome ("butch-femme") relationships, however, seemed to stymie the sexologists and worry the social critics of the day, since unmarried women (that is, shōjo) in particular were stereotypically regarded as blissfully unaware of sexual desire and since females in general were certainly not supposed to play an active role in sex. "Moral depravity" fostered by modernization (westernization) seemed to be the only viable "explanation" for ome relationships among urban women, at least until the appearance of Takarazuka otokoyaku prompted critics to come up with new ideas to account for the increasingly visible masculinized female.

Overall, it seems that the majority of print space was devoted to defending the typicality and relative "normality" of dōseiai (homogender) relationships among shōjo and to insisting on their-ideally, at least-platonic character. Apart from eyecatching headlines and titles, proportionately little attention was paid to the ome relationship itself, although the "origins" of the "abnormal and anomalous" (hentaiteki) masculine partner generated several speculations. The author of a 1930 newspaper article on the Takarazuka Revue, for example, went so far as to assert that the emergence of ome-type relationships was the "direct result of females' playing men's roles," and suggested that the Revue was the medium through which Class $S$ couples were transformed into ome couples, an evolutionary thesis absent from the Fujo Shinbun article published 20 years earlier (Ōsaka Nichinichi, 21 July 1930; see also Yoshiwara 1935:187, for essentially the same argument). The headline summed up the author's argument: "From Class $\mathrm{S}$ to Feverish Yearning for Otokoyaku. ${ }^{\prime 24}$

\section{androgyny as erasure}

The "psychiatric style of reasoning" imported from Europe and the United States late in the 19th century - and alluded to in the 1910 Fujo Shinbun article and others-provided a whole new set of concepts that made it possible to separate questions of sexual and gender identity from facts about anatomy (Davidson 1987:22; see also Hanafusa 1930; Izawa 1931; Kure 1920; Yasuda 1935). Female sexualities, now problematic, were linked to experiences, to environment, and to "impulses, tastes, aptitudes, satisfactions, and psychic traits" (Davidson 1987:22). For example, in the Fujo Shinbun article, "abusive stepmothers, exploitative employers, constant hardship, others' callousness, false accusations, and unrequited love" were blamed for causing girls and women to adopt dōseiai practices. Certain sexologists and social critics regarded the so-called masculinized female in particular as a prime example of a newly defined disorder, "abnormal psychology" (hentai seiri or hentai shinri). After establishing crossdressing (hensō) itself as "abnormal" (fuseijō), one sexology writer went on to distinguish between "natural," or congenital, cross-dressing and "unnatural," or acquired, cross-dressing among females and males. ${ }^{25}$ According to this writer, the former involved an intersexed person 
attempting to pass as either a woman or a man, while the latter involved a person motivated by curiosity, criminal intentions, or the desire to secure a livelihood. Masculinized females associated with the theater, the author claimed, cross-dressed out of curiosity (Tomioka 1938:98-103).

Beginning in the 1920s, so far as I can assess from the print media, Takarazuka otokoyaku as well as the girls and women who were attracted to them (and sent "love letters") were referred to by unsympathetic critics as "abnormal" and "anomalous" (Kawahara 1921:13; Ôsaka Nichinichi, 21 July 1930; Sugita 1935). Their desire was interpreted as being out of alignment with their female bodies. The sympathetic use of the term chüsei ("neutral," or "in between" woman and man) to describe the Takarazuka otokoyaku, and masculinized females in general, conveniently circumvented the issue of erotic desire and parried allegations of "abnormal" sexuality. Chūsei was used defensively to deflect negative attention from both the sexual difference represented by the Takarazuka otokoyaku and the social ramifications of that difference. Describing someone as chūsei suggested that she had a childlike naiveté about anything beyond a passionate friendship between shōjo sisters. A group interview with ten Takarasiennes on their thoughts about a Hungarian movie star known in Japan for her "otokoyakulike" appearance illustrates the deflective, defensive use of chūsei. Active in the 1930s, she is described in the interview as not only neutral (chūseiteki) but also childish (kodomoppoi), mischievous (itazurakko), and "not coquettish, but rather romantic in a childish sense" (kodomoppoi romanchikusa). The reporter notes that she is chūsei, "in the sense of childlike" (chairudo to iu imi), the implication being that despite her provocative wink, she is asexual (Yomiuri Shinbun, 23 May 1935).

Some of the more "progressive" writers and critics sympathetic to the Revue, such as the novelist Yoshiya Nobuko (1904-73), a lesbian, ${ }^{26}$ preferred the safe ambiguity of chūsei, with its allusions-like Yoshiya's fiction-to a "dream world" (yume no sekai) free from the constraints of fixed, dichotomous, and hierarchical gender roles. Takarazuka itself was conceived of as a dream world - "a place where dreams are made and sold," according to the Revue's advertisements-and the early theater complex was named, appropriately, "Paradise" (Paradaisu). Kobayashi collaborated with Yoshiya and shared her romantic vision, but colored it heterosexual: his dream world was one in which gallant men were sustained by adoring women.

Detractors, on the other hand, referred to the otokoyaku and other "modern girls" as abnormal, masculinized females, who sported short hair (danpatsu) and wore pants (Maruki 1929; Sugita 1929:80, 1935). Such females were also called "garçons, ${ }^{\prime 27}$ since they had "forgotten what it means to be feminine," one of the accusations leveled at Yoshiya Nobuko herself (Ōsaka Mainichi, 10 February 1932). If the "good wife, wise mother" was praised as the embodiment of social stability, the masculinized female was criticized as a disturbing sign of the disorder accompanying the growth of the modern, westernized city (Sugita 1929, 1935; Yoshida 1935).

From the mid-1930s onward the expression dansō no reijin, meaning literally "a beautiful person [that is, a female] in masculine attire," was used sympathetically in reference to both Takarazuka otokoyaku and masculinized females. ${ }^{28}$ This expression, a euphemism for chūsei, was apparently coined in 1932 by the novelist Muramatsu Shōfu. His serialized short story "Dansō no reijin" was inspired by Kawashima Yoshiko (1906-48), who had donned a military uniform and passed as a man during the early stages of Japanese imperialism in China and Manchuria. ${ }^{29}$ Several years later, in 1935, the affluent moga Masuda Yasumare (née Fumiko) made headlines as a dansō no reijin when she attempted suicide after her ("butch-femme") love affair with Saijō Eriko of the Shōchiku Revue became public knowledge (Nakano 1935; Saijo 1935; Yashiki 1935). ${ }^{30}$ From a patriarchal perspective, the expression dansō no reijin subordinates the female body to the masculine clothes (dansō) covering it. At the same time, a priori knowledge of the underlying female body neutralizes both the masculinity of the costume 
and, by extension, the "male" gender identity of the female in question. The dansō no reijin is reduced to a caricature of a man, and her sexuality read as ambiguous, unresolved, or un(der)developed-and unthreatening. ${ }^{31}$ Ideologically speaking, when people lack a priori knowledge of the sex of a body, gender must be overdetermined in order to facilitate their perception of that body as either female or male.

Kobayashi's response to the Masuda-Saijō affair in an official Takarazuka fan magazine made problematic the sexual ambiguity of the dansō no reijin figure. In an editorial titled "What is the 'dansō no reijin'?" Kobayashi expressed his concern that the current spate of scandal-mongering press reports on all-female revues was bound to create public misunderstandings about Takarazuka, the " 'main household' [honke] of the shōjo revue":

The dansō no reijin, . . . a symbol of abnormal love, . . . is becoming a social problem. . . Good [that is, upper-class] households especially are affected. . . . Nothing must compromise [Takarazuka's] reputation or worry the parents of [Takarazuka Music Academy] students. [Kobayashi 1935:10-12] ${ }^{32}$

In the editorial, Kobayashi included part of a letter to Ashihara Kuniko, a leading otokoyaku, asking her to make sure that new students understood they were not to use masculine words or to behave in a masculine fashion in their daily lives. ${ }^{33}$ Ashihara's fans called her aniki (elder brother), a matter which distressed Kobayashi greatly and for which he had chastised her two years earlier (Ashihara 1979:157). Her reply-which, in keeping with precedent, may actually have been written by him-was included in the editorial. ${ }^{34}$ In that ostensible reply, the senior otokoyaku reassured Kobayashi that she and "the others are all just 'ordinary girls' ... who practice the tea ceremony and flower arrangement when not performing." Masculine words, she added, "are not used by any of the students or actors even though their use is popular among girls' school students and [Takarazuka] fans" (cited in Kobayashi 1935:11-12). But even sympathetic contemporary accounts of the Revue contradicted this "ordinary girl" image of the Takarasiennes: Hirai, for example, profiled one otokoyaku who was "malelike in her everyday life" (Hirai 1933:168). It appears, rather, that Kobayashi's editorial was a timely and opportunistic measure undertaken not only to deflect any negative repercussions on the Revue from the highly publicized Masuda-Saijō affair but also to reinforce his patriarchal agenda for the Takarasiennes.

\section{conclusion: postwar androgyny}

Here, I will shift from a discussion of largely historical (prewar and interwar) references to androgyny to a consideration of several more recent (postwar) constructions of androgyny in the context of the Takarazuka Revue. Knowledge of precedents and of the early, varied reception of the Revue is essential to an understanding of contemporary experiments with androgyny. The Revue continues both to uphold the dominant ideal of heterosexuality and to inform a lesbian subcultural style. In this connection, the allegorical tension that has marked Takarazuka from the beginning still frustrates the patriarchal management. With respect to state formation (that is, the production and reproduction of the status quo), the Revue continues to attract the attention of the mass media, although the charges of "moral depravity" and "abnormal sexual desire" are rarely leveled, as openly at least, at the Takarasiennes. Suffice it to say for the time being that the waning of overt criticism is due less to a greater tolerance for diverse sexualities than to an avoidance of sexual practices and expressions other than the heterosexual and/or (androcentrically) pornographic.

One of the reasons why the newly revived musical The Rose of Versailles, first staged in the mid-1970s, has been such a success among female fans of all ages is that it dwells on the adventures of Oscar, a female raised as a boy in order to insure the continuity of a patriline of generals. ${ }^{35}$ The Oscar character represents a slippage between sex and gender and is referred to in the literature as a "classic" dansō no reijin (Tsuji 1976:97, 107-108; Yabushita 
1990:108). (See Figure 1.) Significantly, Oscar has been acted exclusively by otokoyaku, whose own acting careers in the Revue have followed a similar trajectory. Clothing is the means to, and even the substance of, the character's commutable gender, as the expression dansō no reijin suggests; accordingly, Oscar switches at one point from masculine to feminine attire. The alternative subtextual meaning of this play is that gender as performance undercuts the ideological fixity of received gender differences (Kuhn 1985:53; see also Komashaku 1989; Tsuji 1976:107-130).

The Rose of Versailles is one of the Revue's most reflexive productions in that the relationship between Oscar and her/his father is analogous to that between the otokoyaku and the Revue's patriarchal directorship. When reading the following dialogue between Oscar and the General, bear in mind that Kobayashi had insisted that Takarasiennes call him "Father":

Oscar: Father, please answer me!

General: Oscar?!

Oscar: If . . . if I had been raised as an ordinary female, would I have been forced to marry at age 15 like my sisters? I could be playing the clavichord, singing arias, dressing up every night in fine clothes and laughing away the time in high society. . . .

General: Oscar!!

Oscar: $\quad$ Please answer me! I could be wearing velvet beauty marks and rose perfume; I could fill my arabesque compact with cosmetics; I could bear children-and raise them.

General: Oscar!!

Oscar: Answer me, please!

General: (Pensively.) Yes, it's as you say-had you been raised as an ordinary female.

Oscar: Father, thank you.

General: (Is taken aback.)

Oscar: Thank you for giving me a chance to live the kind of life I have, in as broad a world as I have, even though I am a female. Even while struggling to deal with the stupidity of pathetic people....

General: Oscar.

Oscar: I am no longer remorseful. I . . I'll live as the child of Mars, god of war. I'll devote this body of mine to the sword; I'll devote it to the cannon. My livelihood is the military and I'll serve as the child of Mars, god of war. [lkeda Riyoko, cited in Tsuji 1976:165-166]

Oscar (and by the same token, the Takarazuka otokoyaku) is able to transcend the fixed, narrow life course of "ordinary females" because of Father's pragmatic decision to name her "son." Recognizing that "male" gender affords access to a wider world, Oscar is effusively grateful for the opportunity to be the household's otokoyaku. Oscar's military uniform not only accentuates the difference between masculinity and femininity - the former identified with swords and cannons, the latter with flowers and children-but magnifies the tension between "male" gender and the female body it camouflages. The overall effect at once exaggerates and masks the slippage between sex and gender. Both the General and the audience know that Oscar, like the Takarasienne, is a masculinized female. That gender is a property of attribution and convention, and not anatomy, is made doubly obvious by the synonymy between Oscar and the otokoyaku performing Oscar. At the same time, both demonstrate the irony that access to a supposedly more "liberating" gender identity is granted by privileged father figures. ${ }^{36}$

In the fall of 1985, the Takarazuka Revue staged a show called Androgyny (Andorojenii), which the (male) playwright/director felt captured the "bewitching charm" of the androgyne. The show called for otokoyaku to appear alternately as "neutral boys" (nyutoraru boi), resplendent in gaudy, glittery jumpsuits and equally colorful wigs, and as well-known (non-Japanese) masculinized females, such as George Sand. Fan magazines described it as a show "ahead of its time" and "unprecedented" (Mure 1985:38).

Although the 1985 revue may have been the first show titled Androgyny, the theme and phenomenon themselves have constituted an essential part not only of the Takarazuka Revie's repertoire but also of its public image, as I have discussed. Moreover, in the late 1960s otokoyaku were encouraged to impart an "androgynous charm" by blending markers of "female" and "male" gender. They did so mainly by ratting their often peroxided hair to create puffy pompadours and by using pastel makeup to soften the darker, sharper, deeply chiseled features 


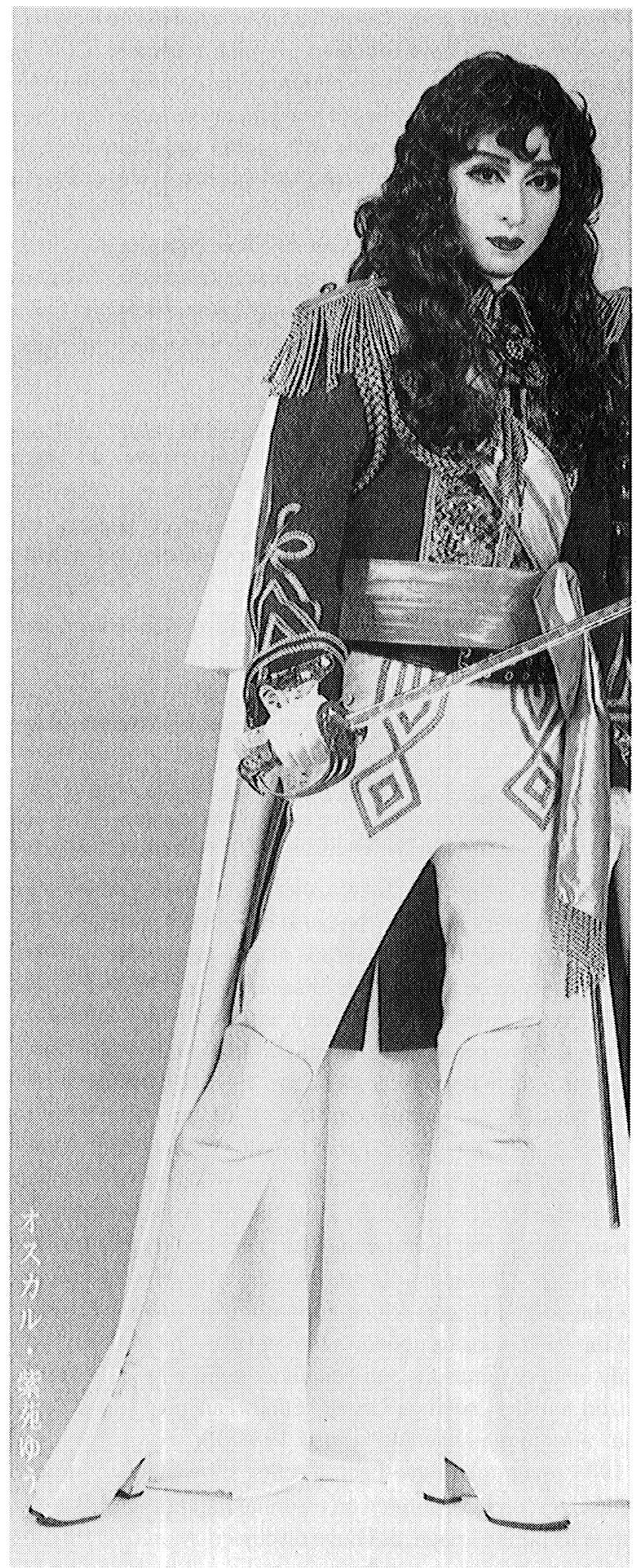

Figure 1. Oscar, acted by otokoyaku Shion Yū in the 1990 production of The Rose of Versailles. Photograph from the program (Takarazuka Kagekidan 1990). 
of the "classic" otokoyaku (see Figures 2 and 3). These 1960s otokoyaku foreshadowed the interstitial Oscar character: Kō Nishiki described herself as "an otokoyaku who was close to being feminine," although she also threatened to resign if forced to appear as a woman on stage (Okazaki 1971:49; Yoshizawa 1966:52); Anna Jun claimed to have been a "womanish" (onnappoi) otokoyaku (Anna 1979:197); Dai Takiko declared that even though she was a "leading man," she took care not to forfeit her femininity (Yamada 1968:70).

By allowing "the woman" to permeate "the man," these otokoyaku in effect drew attention to the facticity of their female bodies and, from the standpoint of convention, to the primacy of their femininity, thus ensuring that their secondary, "male" gender was kept in check by their primary, "female" gender. The directors did not want the otokoyaku to be too successful in her appropriation and performance of masculinity. Similarly, as a way of clarifying the limits of the actors" "honorary" masculinity, the directors staged shows in which otokoyaku were to appear as women, much to the consternation of the actors and their fans. Allowing "the woman" to permeate "the man" was one thing, but being assigned to women's roles was quite another. Many otokoyaku protested the directors' gender-switching antics and claimed to have experienced a sense of conflict or resistance (teikō), along with a loss of confidence (Misato 1974:68; Okazaki 1971:49; Takarazuka Gurafu 1977:38; Yamada 1968:70-71; Yoshizawa 1967:71). Gō Chigusa, an otokoyaku who retired in 1972, remarked that on the rare occasion she was assigned to perform as a woman, her fans complained bitterly of their resultant dis-ease ( $\mathrm{kim}$ ochi warui), that eerie feeling when the familiar is suddenly defamiliarized (Yoshizawa 1967:71). The androgynous charm of the otokoyaku was compromised by the compulsory femininity of "the woman."

Otokoyaku have been characterized as "sexy but sexless," the argument being that ambiguous gender translates as an asexual identity (Asahi Shinbun, Osaka ed., 21 December 1977). An otokoyaku performing on stage as a man may be the object of desire, but she herself is purportedly without sexuality. Partly to rationalize and sustain the perception of asexuality, all Takarasiennes must remain unmarried, and ostensibly heterosexually inexperienced, throughout their tenure in the Revue-a policy implemented by Kobayashi at the founding of the Revue. Implicitly acknowledging that a theatrical vocation virtually precludes distinctions between on- and offstage experiences, several otokoyaku have noted that "it would be ridiculous to be married and perform as a man on stage," but their explanation contradicts the management's rationale: "Female fans probably will not be charmed by a married otokoyaku" (Kageki 1962:41). From the beginning, the Revue management has sought to limit the female fans' infatuation to the ideal man performed by an otokoyaku. My archival research and interviews suggest that, on the contrary, female fans of all ages, classes, and educational levels do not see a man on stage, but rather acknowledge a female body performing in a capacity that transgresses the boundaries of received femininity (Hoshi 1987; Maruo 1950:252-278; Ōsaka Jiji, 12 December 1934; Fujin Kōron 1935; Tanabe and Sasaki 1983:135-136). ${ }^{37}$ The otokoyaku, in short, is appreciated as an exemplary female who can successfully negotiate both genders, and their attendant roles, without being constrained by either.

Much of the Euro-American literature on androgyny deals with nonethnographic theoretical issues, with film and literary characters (for example, Bell-Metereau 1985; Bergstrom 1991; Butler 1990; Heilbrun 1982 [1964]; Pacteau 1986; Stimpson 1989 [1974]), or with intersexed and transsexed bodies (for example, Foucault 1980 [1978]; Millot 1990 [1983]). I have benefited from this insightful literature in devising strategies for making visible the construction and uses of androgyny in Japan as a "surface politics of the body." However, I have tried to avoid the tendency to force Japanese cultural practices into Western analytical categories. Of course, moments and sites of historical conjunction must be acknowledged, and cultural practices should be distinguished from the dominant gender ideology operating in Japan.

My work also differs from the Euro-American literature in that I have aimed to show how androgyny has been constructed, performed, practiced, and deployed by real females and 


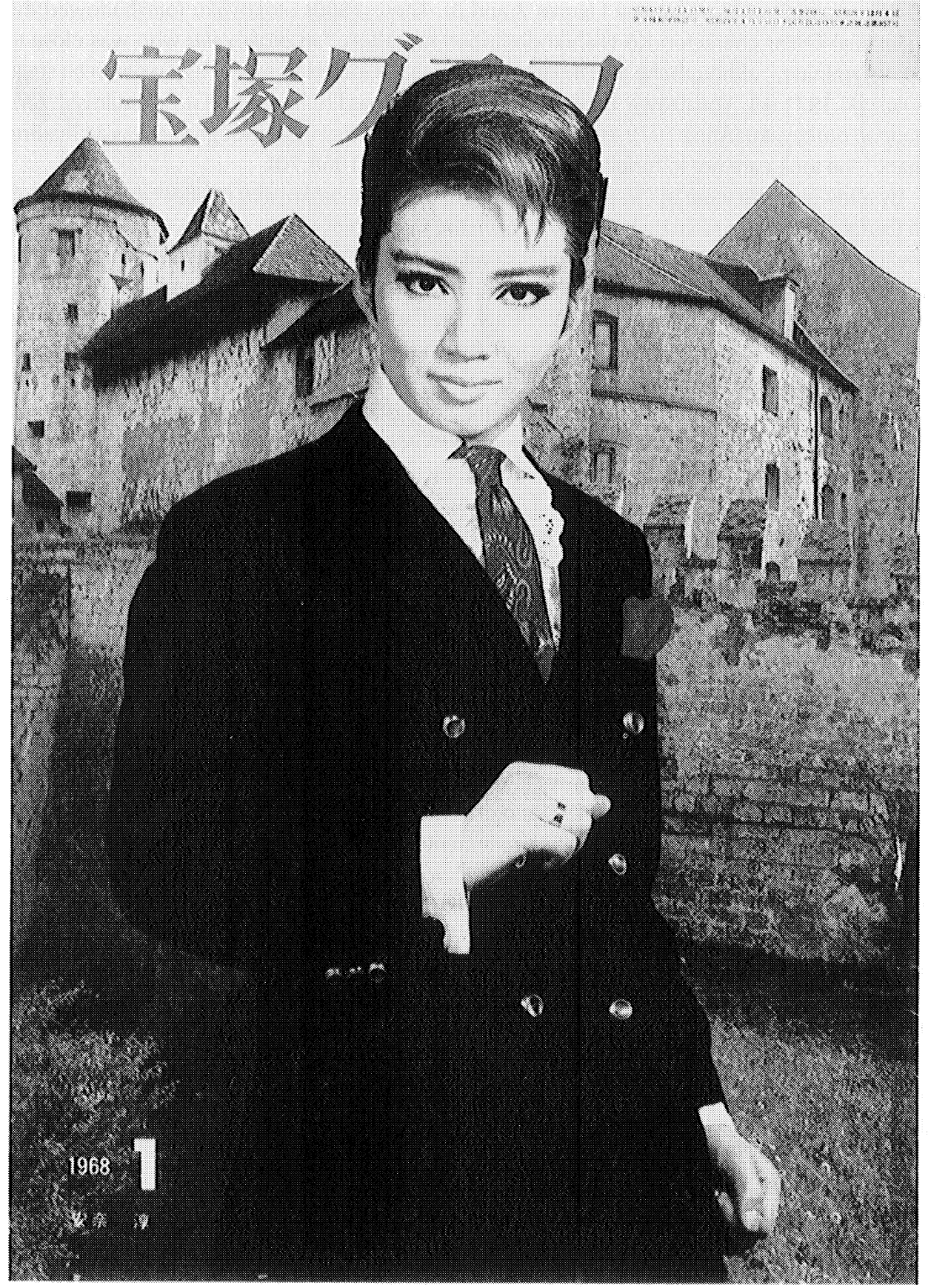

Figure 2. Anna Jun as a 1960s "androgynous" otokoyaku. Photograph from the cover of Takarazuka Gurafu (Fujii 1968). 


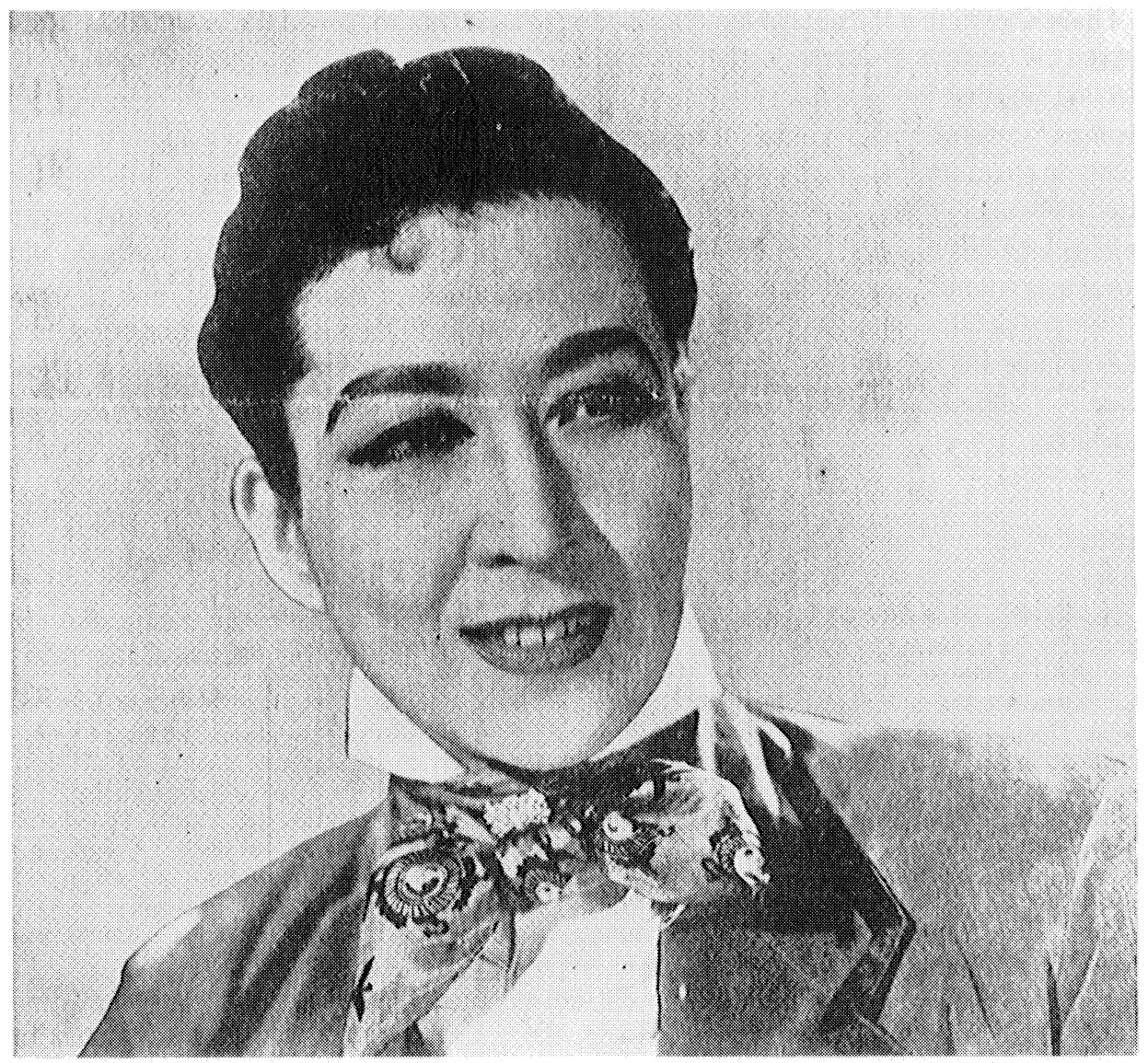

Figure 3. Kasugano Yachiyo as a "classic" otokoyaku. Photograph from the cover of Takarazuka Fuan (Kishi 1954).

males, who include the Takarazuka actors, their fans, and their critics. Bergstrom's discussion of the dual iconicity of androgyny, for example, closely resembles my discussion of the terms ryōsei and chūsei: "Where androgyny, as a fashionable, contemporary look, can indicate 'more' sexuality, meaning both feminine and masculine appeal, virtually the same image can be used to signal the eradication of sexuality" (1991:36). But whereas her cogent analysis. is based on Calvin Klein underwear advertisements and select science fiction films, I have shown how the different semantic and semiotic values of androgyny were actually (re)produced and deployed by Japanese females and males on and off the Revue stage.

In Japan the term chūsei has been used since the turn of this century to name three basic, but overlapping, types of females: those whose bodies approximate the masculine stereotype; those who are charismatic, unconventional, and therefore not feminine females; and those who have been assigned to do "male" gender or who have appropriated it on their own initiative. The characterization of their appearance as "androgynous" is necessarily premised on a priori knowledge of the underlying female body_knowledge that nullifies or compromises the "male" gender of the surface. It goes without saying that a female who passes successfully as a man does not appear androgynous. ${ }^{38}$ The androgynous appearance of masculinized females has been read by some as not only "abnormal" but a sign of their asexuality. The expression dansō no reijin directed attention away from the body and toward the masculine clothing of a female who made unconventional choices, sexual and otherwise. 
I have shown that the appeal to and experiments with androgyny in the Takarazuka Revue served the interests of the patriarchal management and the female actors and fans alike by deflecting negative attention from the sexual difference posed by the otokoyaku. By allowing "the woman" to permeate "the man," the experiments with androgyny in the late 1960 s and early 1980 s in effect emphasized the facticity of the female body doing "male" gender. The directors used these experiments to ensure that an otokoyaku's secondary, "male" gender would be kept in check by her primary, "natural" femininity. Female fans, on the other hand, saw the otokoyaku as a female unconstrained by a sexual and gendered division of labor. Androgyny, as a "surface politics of the body," has been used historically to interrogate the naturalized dualities of male and female, masculine and feminine. By the same token, androgyny has also been used-in various ways by various agents-to exaggerate, essentialize, and mystify those dualities.

\section{notes}

Acknowledgments. My fieldwork and archival research in Japan (Tokyo, Kyoto, and Takarazuka) were funded by the following fellowships and grants: Japan Foundation Professional Fellowship (June-September 1987); Northeast Asia Council of the Association for Asian Studies Grant (June-September 1987); Social Science Research Council Research Grant (June-September 1987); University of California, San Diego, Japanese Studies Program Travel Grant (summer 1987); University of California, San Diego, Affirmative Action Faculty Career Development Grant (July_-September and November-June 1989—90); Fulbright Research Grant (January-August 1990). Abridged versions of this article were presented as "The Androgynous Body in Japan," at the American Ethnological Society Annual Meeting, Atlanta, 19-22 April 1990; as "The Image of the Androgyne: Female Sexualities in Modern Japan," at the E. O. Reischauer Institute of Japanese Studies, Harvard University, 12 October 1990; and as "The Politics of Androgyny in Japan," at the Japan Colloquium, University of California, Los Angeles, 31 May 1991. Thanks are due to the four anonymous reviewers for their informative critiques, to Don Brenneis and Kris Fossum for their editorial expertise, and to Maria Teresa Koreck for her insightful reading.

All translations from Japanese to English are my own unless otherwise indicated. For Japanese individuals, the family name precedes the given name.

'By "the state," I mean not simply an "organ of coercion" or a "bureaucratic lineage" but a "repertoire of activities and institutions" that shape and are shaped by sociohistorical circumstances and experiences (Corrigan and Sayer 1985:2-3). Although for the sake of convenience I refer to the state as a thing in itself, namely, "the state," I regard the state as an "ideological project," an "exercise in legitimation" (Phillip Abrams, cited in Corrigan and Sayer 1985:8).

${ }^{2}$ Yasui (1953) notes that a vernacular expression for androgyny is otoko-onna-literally, "manwoman"- -although references to androgyny in social scientific, literary, and scientific writings tend to be limited to the terms ryōsei and chūsei.

${ }^{3}$ Jung proposed that all people were androgynous; any person, whether female or male, had both a feminine side and a masculine side. "Anima" was his term for the feminine archetype in males, "animus" for the masculine archetype in females. The sexist essentialism of Jung's proposal is evident in his description of these terms. The anima included irrationality, spirituality, and emotionalism, and the animus rationality, courage, and strong convictions (Hyde and Rosenberg 1980 [1976]:19).

${ }^{4}$ The jo in josei may also be read as onna, and the dan in dansei as otoko.

${ }^{5}$ Although a female, the legendary dancer Okuni from Izumo, is credited with having initiated Kabuki at the start of the 17th century, females have been banned from that stage since 1629. Apparently, the newly installed Shogunate was disturbed by the general disorder, including unlicensed prostitution, following the performances, when patrons quarreled with one another for access to their favorite dancers. Replacing the females with boys did not solve the problem, for the male patrons were equally attracted to the boys. Eventually, the prohibition of females and later of boys prompted the sanctioned emergence of the onnagata, adult males who specialized in femininity.

${ }^{6}$ For a more detailed discussion of the Revue's early history, see Robertson 1989 and $1991 \mathrm{~b}$.

7The Takarasiennes, in short, specialize in performing "male" and "female" gender. However, the Revue has never staged a play featuring contemporary Japanese characters (other than patriotic youths in wartime productions). Plays with Japanese characters are limited to stories set in the Heian through Edo periods, roughly the 9 th through the mid-19th century. Plays set in the 20th century present non-Japanese "male" and "female" characters exclusively. Thus, the repertoire of an otokoyaku does not include contemporary Japanese men, although the Takarasienne learns about masculinity by watching, among others, Japanese males. The representation of contemporary Japanese "male" gender appears to be off-limits to Takarazuka otokoyaku. 
${ }^{8}$ Asano (1989) notes that there are several sutras written to facilitate the henjo nanshi process and that certain unorthodox sects, such as the Fujikō (late 16th century), Nyoraikyō (late 18th century), and Ōmotokyō (early 20th century), incorporated the concept of androgyny qua "cross-dressing" into their doctrines and ritual practices.

${ }^{9}$ Otoko ga onna ni nari yaku o enjiru.

${ }^{10}$ Onna de aru otoko ga yaku o enjiru.

"Onnagata wa nichijōteki ni onna de aru koto. An Ayamian onnagata is more specifically referred to as a ma no onnagata, or "true" onnagata, in contradistinction to some present-day Kabuki actors who perform as onnagata in addition to taking on a plethora of "male" roles.

${ }^{12}$ The primer was written by Kaibara Ekken, a leading representative of the "practical school" of Confucianism and a self-appointed critic of females. Ekken proclaimed that while necessary for the reproduction of male heirs, female genitalia promoted dull wittedness, laziness, lasciviousness, a hot temper, and a tremendous capacity to bear grudges. He was not alone in suggesting that a female-sexed body was contrary to and even precluded "female" gender (see Robertson 1991a).

Political leadership during the Edo period was monopolized by the Tokugawa clan under the leadership of the shogun, who ruled from the capital city of Edo. The Confucian orientation of the Shogunate was reflected in the four-part social status hierarchy, in which samurai occupied the top rank, followed by farmers, artisans, and merchants. Actors, along with outcastes and criminals, were lumped into a fifth, "nonpeople" category below the merchants. Although individuals of higher status could fall, those of the lowest status could not rise. Kabuki was among the literary, fine, and performing arts whose development accompanied the consolidation of a mercantilistic urban culture during this period.

${ }^{13}$ The term futanarihira is also a play on the name of Arihara no Narihira, a 9th-century bisexual courtier eulogized in Edo-period fiction as "the god of yin and yang" (Schalow 1990:10). The futa (double) preceding narihira would seem to imply an "overdetermined" Narihira, or perhaps a "body-double" Narihira.

${ }^{14}$ In 1868 the Shogunate was defeated by anti-Tokugawa court nobles, and the emperor (who adopted the reign name of Meiji) was restored to power.

${ }^{15}$ The civil code promulgated during the Meiji period (1868-1912) was operative from 1898 to 1947.

${ }^{16}$ For more information in English on the "woman problem," see Nolte and Hastings (1991), Sievers (1983), and Silverberg (1991).

${ }^{17}$ In 1990, the expression ojin gyaru (older man-gal) was coined to refer to "gals" who enjoy drinking, gambling, and singing (karaoke-style) after work, presumably just like their fathers and other older men. There is even an ojin gyaru anthem, "Senchimentaru gyaru" ("Sentimental Gal"), which was broadcast regularly in the spring of 1990 on the government television station's (NHK) weekly hit parade. The phrase ojin gyaru suggests androgyny inasmuch as it refers to a female who has appropriated masculine pastimes.

${ }^{18}$ Tomioka refers to such women as examples of "acquired 'male' impersonation" (kotenteki dansō), although he notes that these "working women are not mentally disturbed, but rather passing as men in order to earn a livelihood" (1938:103). It is clear from his article, especially the section on "inherent [sententeki] 'male'/'female' impersonation," that he uses "cross-dressing" to mean androgyny. Generally speaking, his "inherent" androgyny corresponds to ryōsei, and his "acquired" androgyny to chūsei.

${ }^{19}$ On 2 April 1940, a Shin Nippō newspaper article on a leading Takarasienne appeared under the headline "Still a Shōjo at 36!" Takarasiennes were by definition unmarried, but the reporter was drawing attention to the disturbing lack of correspondence between chronological age and shöjo status. The same point had been made 15 years earlier in a newspaper series on shöjo theater groups (Ōsakato, 15, 17-20, and 22 July 1925).

${ }^{20}$ The Meiji government ruled in 1872 that primary education, if sex segregated, was compulsory for girls and boys alike, although home economics constituted the bulk of education for girls. Public and private secondary schools for girls and young women, called "higher schools," were established countrywide in the early 1900s, and by 1907, 40,273 female students were enrolled in 133 higher schools (Pflugfelder 1989:7). For a comparative perspective, see Vicinus' work on English boarding school friendships (1989).

${ }^{21}$ Early 20th-century sexologists used the term dōseiai (literally, "same-sex love") for homosexuality and the term iseiai (literally, "different-sex love") for heterosexuality (see, for example, Kure 1920). These and other terms appeared not only in specialized medical journals but also in a wide range of print media, including novels and women's newspapers and journals; they were thus familiar to a broad spectrum of literate people.

Although dõseiai is a generic term, it is defined more specifically in this particular article as an essentially platonic if passionate relationship. Ome is an abbreviation of osu (male) and mesu (female), terms reserved for plants and animals and applied pejoratively to humans. An 1818 reference to ome refers not to a same-sex couple but to an androgyne, in this case a female who passed as a man (Tomioka 1938:102).

${ }^{22}$ The author was alluding to the fact that the "male" partner was not intersexed but had a "normal" female body.

${ }^{23}$ Shinkeishitsu originated around the turn of the century as a category of sociosexual disease, diagnosed most often in urban middle-class women (who represented about 30 percent of the female population at that time).

${ }^{24}$ In a 1934 newspaper interview, a Japanese sexologist drew distinctions between what he called "pseudo-homosexuality" (gisei dōseiai) and "true homosexuality" (shinsei dōseiai), the former consisting 
of a "transitory love relationship" (awai ren'ai kankei) and the latter of "actual sexual practices" (honkakuteki na seikoi). According to his criteria, Class S relations would fall into the category of pseudo-homosexuality and ome relations into that of true homosexuality (Hori Kentarō, cited in Ósaka Mainichi, 31 January 1935). See Robertson (1989) for expressions used by Takarasiennes for female-female couples.

${ }^{25}$ The writer used "cross-dressing" where others used "androgyny," and he tucked information about contemporary practices between long accounts of Edo-period cross-dressers, possibly as a way to avoid the wartime censors.

${ }^{26}$ Yoshiya, an openly recognized lesbian, wrote popular, widely disseminated articles and short stories on such topics as "same-sex love," the superfluousness of husbands, and patriotism. The mass media referred to Yoshiya and her life-partner, Monma Chiyo, as a dōseiai füfu (same-sex love husband and wife) (Usumi 1935:43).

${ }^{27}$ The use of garçons probably reflects the French influence on the development of the all-female revue and the role of the "male" gender specialist.

${ }^{28} \mathrm{~A}$ variant of this expression appears in a 1935 newspaper (Ōsaka Mainichi, 15 January) article as dansō no reijō, literally, a "beautiful [unmarried] female in masculine attire."

${ }^{29}$ Kawashima, born into the Chinese royal family but raised by her adopted family in Japan, began to wear men's clothes at the age of 16 (Kamisaka 1984:87). She was eventually executed in Japan on charges of treason. Muramatsu's short story was serialized in a leading women's journal, Fujin Kōron.

${ }^{30}$ Founded in Tokyo (Asakusa) in 1928, the all-female Shōchiku Revue later established an Osaka branch (near Takarazuka) and quickly became Takarazuka's main rival in every respect. From the start, the Shōchiku Revue, which was formally disbanded in early 1990 (although special performances are to be scheduled annually), was cast as the opposite of Takarazuka. For example, where Takarazuka productions were stereotyped as naive and romantic, the Shōchiku actors performed allegedly more mature and erotic revues. Fans partial to one revue rarely attended performances staged by the rival troupe. Moreover, following the establishment of the Tokyo Takarazuka theater in the Ginza area in 1934, an areal distinction was drawn between the two revues. Takarazuka was cast as an "uptown" theater attractive to girls and women from wealthy households, and Shōchiku as a "lowtown" theater appealing to a blue-collar clientele.

Mizunoe Takiko (Tākii), Shōchiku's leading otokoyaku for decades, was the first revue actor to cut her hair short and is the subject of many books and articles. Generally speaking, articles, books, and, in recent decades, television programs on Takarazuka far outnumber those on the Shōchiku Revue. See Robertson (1989) for an account of same-sex ("butch-femme") affairs in the Takarazuka Revue.

${ }^{31}$ Although it would seem that the reasoning behind the concept of dansō no reijin fits the experience of the Kabuki onnagata, the two are not symmetrical. Whereas the former is reduced to a caricature of a man, the latter is promoted as a paragon of femininity. The asymmetry reflects the arbitrary operations of a dominant ideology premised on male dominance and agency.

${ }^{32}$ Kobayashi's concern about upper-class households reflects the fact that Masuda was from a wealthy family, as was (and is) the typical Takarazuka student.

${ }^{33}$ For Kobayashi, the most problematic "male" words were aniki (elder brother), boku (a self-referent denoting "male" gender), and kimi (a masculine form of "you") (Kobayashi 1935).

${ }^{34}$ Ashihara suspected Kobayashi of forging a letter detailing a fan's negative reaction to her nickname, aniki (Ashihara 1979:157).

${ }^{35}$ In 1989, the play was revived-to satisfy nostalgic "old fans" and attract new fans. A two-year run was planned. The Rose of Versailles, by Ikeda Riyoko, was serialized from 1972 to 1974 in the weekly Margaret and published in several volumes in 1983 (Ikeda 1983).

${ }^{36}$ Kuhn observes that if "clothing can be costume, capable of being modified at the wearer's will, it follows that the gender identity conventionally signified by dress may be just as easily changeable $e^{\prime \prime}$ $(1985: 53)$. What is most problematic about this theoretical statement with respect to the Takarazuka otokoyaku is the matter of the "wearer's will." "Will" does not figure in one's initial gender assignment (based on genitalia), nor is a Takarasienne's secondary gender assignment necessarily congruent in every respect with her will.

Interestingly, in recent decades Takarasiennes and their fans have sometimes referred to the otokoyaku as a female who has metamorphosed (henshin shita) (Takarazuka Gurafu 1986), indicating a recontextualization of this hitherto androcentric term to fit their stage experience. Their use of the term outside the Buddhist and Kabuki (onnagata) contexts may have been prompted by the tremendous continuing popularity of the "henshin dramas" (dorama) that were first aired in the late 1960s. These television dramas, some of them animated, feature mostly "ordinary" boys and young men who have the ability to change (henshin) suddenly into other, more powerful forms. In another incarnation the brainy Pa-man, for example, is Mitsuo-kun, an average elementary school student. His inventors suggest that what audiences find intriguing is the possibility of "one person living in two worlds" (Asahi Shinbun, Osaka ed., 13 January 1968). Many comic book characters and toy robots (such as Transformers) are also based on the idea of henshin.

${ }^{37}$ Since the postwar period (roughly the 1950s onward), females of all ages have constituted the overwhelming majority of the Takarazuka audience and fan population. Throughout the prewar and interwar years, about half of the audience was made up of males, although the most zealous (and problematic) fans 
were female. The unabated postwar popularity of Takarazuka among females probably has much to do with the dominant gender ideology. Voting rights (1947) and nominal equal employment opportunity laws (1986) notwithstanding, sexist discrimination-from the boys-first order of school roll calls to short-term "mommy track" jobs - is the prevailing state of affairs. The gender "norm" of "women inside, men outside" is reinforced by "public opinion" polls commissioned by the Prime Minister's Office and others, despite the fact that over 60 percent of all adult females - 80 percent of them married and mothers-work for wages outside the home (see Asahi Shinbun, Osaka ed., 29 March 1990; Atsumi 1988; Japan Times, 10 April 1990).

${ }^{38}$ In Gender Blending, Devor's use of the term "androgyny" is different from mine here. She presents the life histories of females who do not consciously attempt to pass as men but who, because of their appearance, are perceived as such (1989).

\section{references cited}

\section{Akiyama Satoko}

1990 Ryōseiguyūsei to seitōsaku. Imago 1(2):57-61.

Anderson, Benedict

1983 Imagined Communities: Reflections on the Origin and Spread of Capitalism. New York: Schocken Books.

Anna Jun

1979 "Berubara" de taitō shita iroke no enshutsu. Fujin Kōron, August:196-201.

Asano Michiko

1989 Minshu shūkyō ni okeru ryōseiguyūkan. In Shiriizu: Josei to bukkyō. Vol. 2: Sukui to oshie. Nishiguchi J. and Osumi K., eds. pp. 200-229. Tokyo: Heibonsha.

Ashihara Kuniko

1979 Waga seishun no Takarazuka. Tokyo: Zenbonsha.

Atsumi, Reiko

1988 Dilemmas and Accommodations of Married Japanese Women in White-Collar Employment. Bulletin of Concerned Asian Scholars 20(3):54-62.

Bell-Metereau, Rebecca

1985 Hollywood Androgyny. New York: Columbia University Press.

Bergstrom, Janet

1991 Androids and Androgyny. In Close Encounters: Film, Feminism, and Science Fiction. C. Penley, E. Lyon, L. Spigel, and J. Bergstrom, eds. pp. 33-60. Minneapolis: University of Minnesota Press.

Butler, Judith

1990 Gender Trouble: Feminism and the Subversion of Identity. New York: Routledge.

Corrigan, Philip, and Derek Sayer

1985 The Great Arch: English State Formation as Cultural Revolution. London: Basil Blackwell.

Davidson, Arnold

1987 Sex and the Emergence of Sexuality. Critical Inquiry 14:16-48.

Devor, Holly

1989 Gender Blending: Confronting the Limits of Duality. Bloomington: University of Indiana Press.

Foucault, Michel, ed.

1980[1978] Being the Recently Discovered Memoirs of a Nineteenth-Century French Hermaphrodite.

R. McDougall, trans. New York: Pantheon Books.

Fujii Kenzō, ed.

1968 [Cover photograph.] Takarazuka Gurafu 248.

Fujin Kōron

1935 Shōjo kageki o kataru—musume to haha no kai. Fujin Kōron, April:288-297.

Fukushima Shirō, ed.

1984[1935] Fujinkai sanjūgonen. Tokyo: Fuji Shuppansha.

Fukutomi Mamoru

1985 "Rashisa" no shakaigaku. Kōdansha gendai shinsho 797. Tokyo: Kōdansha.

Gunji Masakatsu

1988 Kabuki to nō no henshin, henge. Shizen to Bunka 19:4-9.

Hanafusa Shirō

1930 Petchi, ruiza, sono hoka. Hanzai Kagaku, December:75-79.

Hara Kie

1987 Fujin Kōron. In Fujin zasshi kara mita 1930 nendai. Watashitachi no rekishi o tsuzuru kai, ed. pp. 16-46. Tokyo: Dōjidaisha.

Hattori Yukio

1975 Hengeron: Kabuki no seishinshi. Tokyo: Heibonsha.

Heilbrun, Carolyn

1982[1964] Toward a Recognition of Androgyny. New York: Norton.

Hirai Fusato

1933 Takarazuka monogatari. Tokyo: Shōjo Gahō. 
Hoshi Sumire

1987 Ano onna (hito) e no rabu reta. Bessatsu Takarjima 64:54-55.

Hyde, Janet, and B. G. Rosenberg

1980[1976] Half the Human Experience: The Psychology of Women. Lexington, MA: D. C. Heath.

Hyūga Akiko

1971 Sei no henshin ganbō. Dentō to Gendai 2(6):26-37.

Ichikawa Hiroshi

1985 "Mi" no kozo: Shintairon o koete. Tokyo: Aonisha.

Ifukube Takaki

1932 Dōseiai e no ikkōsatsu. Hanzai Kagaku, January:290-293.

Ikeda Riyoko

1983 Beusaiyu no bara (The Rose of Versailles). Tokyo: San'yūsha.

Imao Tetsuya

1982 Henshin no shisō. Tokyo: Hōsei Daigaku.

Izawa Mitsuki

1931 Dōseiaikō. Hanzai Kagaku, September:224-228.

Kabeshima Tadao, Hida Yoshifumi, and Yonekawa Akihiko

1984 Meiji Taishō shingo jiten. Tokyo: Tōkyodo.

Kageki

1962 Jidai ni kakaru hashi: San'nin musume no merodorama hōdan. Kageki 444:38-44.

Kamisaka Fuyoko

1984 Dansō no reijin: Kawashima Yoshiko den. Tokyo: Bungei Shunjū.

Kawahara Yomogi

1921 Takarazuka kageki shōjo no seikatsu. Osaka: Ikubunkan.

Kessler, Suzanne, and Wendy McKenna

1985[1978] Gender: An Ethnomethodological Approach. Chicago: University of Chicago Press.

Kishi Sumie, ed.

1954 [Cover photograph.] Takarazuka Fuan 93.

Kobayashi Ichizō

1935 "Dansō no reijin" to wa? Kageki 169:10-12.

1960 Takarazuka manpitsu. Tokyo: Jitsugyō no Nihonsha.

Kōjien

1978a S.v. rashii. In Kōjien. Tokyo: Iwanami Shoten.

1978b S.v. sei. In Köjien. Tokyo: Iwanami Shoten.

Komashaku Kimi, ed.

1989 Onna o yosou. Tokyo: Keiso Shobo.

Komine Shimoe and Minami Takao

1985 Dōseiai to dōsei shinjū no kenkyū. Tokyo: Komine Kenkyūjo.

Koyama Shizuko

1982 Kindaiteki joseikan to shite no ryōsaikenbo shisō. Joseigaku Nenpō 3:1-8.

1986 Ryōsaikenboshugi no reime. Joseigaku Nenpō 7:11-20.

Kuhn, Annette

1985 The Power of the Image: Essays on Representation and Sexuality. London: Routledge and Kegan Paul.

Kure Hidemitsu

1920 Dōsei no ai. Fujin Gahō, October:24-27.

Maeda Isamu

1973 Edogo daijiten. Tokyo: Kōdansha.

Maruki Sunado

1929 Modan kigo. Kaizō, June:29-32.

Maruo Chōken

1950 Takarazuka sutā monogatari. Tokyo: Jitsugyō no Nihonsha.

Millot, Catherine

1990[1983] Horsexe: Essay on Transsexuality. K. Hylton, trans. New York: Autonomedia

Misato Kei

1974 Sutā no tankyū. Takarazuka Gurafu 326:68-69.

Mitsuda Kyōko

1985 Kindaiteki boseikan no juyō to henkei. In Bosei o tou. Wakita H., ed. pp. 100-129. Tokyo: Jinbun Shoin.

Miyasako Chizu

1986 Nakahara Atsukazu no hikari to kage. Shōjoza 2:58-61.

Mosse, George

1985 Nationalism and Sexuality: Middle-Class Morality and Sexual Norms in Modern Europe. Madison: University of Wisconsin Press.

Murakami Nobuhiko

1983 Taishōki no shokugyōfujin. Tokyo: Dōmesu Shuppan.

Mure Kō

1985 '85nen kōenhyō: Tendā Guriin, Andorojenii. Takarazuka Gurafu 462:38-39. 
Nakano Eitarō

1935 Dansō no reijin to Saijō Eriko. Fujin Kōron, March:161-167.

Nolte, Sharon, and Sally Hastings

1991 The Meiji State's Policy towards Women, 1890-1910. In Recreating Japanese Women, 16001945. G. Bernstein, ed. pp. 151-174. Berkeley: University of California Press.

Okazaki Fumi

1971 Miwaku no sutā, Kō Nishiki. Takarazuka Gurafu 287:48-51.

Ōzumi Isan

1931 Hentai seiyoku. Hanzai Kagaku, April:75-83.

Pacteau, Francette

1986 The Impossible Referent: Representations of the Androgyne. In Formations of Fantasy. V. Burgin, J. Donald, and C. Kaplan, eds. pp. 62-84. New York: Methuen.

Pflugfelder, Gregory

1989 "Smashing" in Cross-Cultural Perspective: Japan and the United States. MS, files of the author.

Rich, Adrienne

1976 Of Woman Born: Motherhood as Experience and Institution. New York: Norton.

Robertson, Jennifer

1989 Gender-Bending in Paradise: Doing "Male" and "Female" in Japan. Genders 5:50-69.

1991a The Shingaku Woman: Straight from the Heart. In Recreating Japanese Women, 1600-1945.

G. Bernstein, ed. pp. 88-107. Berkeley: University of California Press.

1991b Theatrical Resistance, Theatres of Restraint: The Takarazuka Revue and the "State Theatre" Movement. Anthropological Quarterly 64(4):165-177.

Saijô Eriko

1935 Dansō no reijin, Masuda Fumiko no shi o erabu made. Fujin Kōron, March:168-178.

Sakabe Kengi

1924 Fujin no shinri to futoku no kisō. Tokyo: Hokubunkan.

Sawada Bushō

1921 Onna ga shujutsu o ukete otoko ni natta hanashi. Fujin Kōron, August:59-70.

Schalow, Paul

1990 Introduction. In The Great Mirror of Male Love. Ihara Saikaku. P. Schalow, trans. pp. 1-46. Stanford, CA: Stanford University Press.

Shida Aiko and Yuda Yoriko

1987 Shufu no Tomo. In Fujin zasshi kara mita 1930 nendai. Watashitachi no rekishi o tsuzuru kai, ed. pp. 48-121. Tokyo: Dōjidaisha.

Sievers, Sharon

1983 Flowers in Salt: The Beginnings of Feminist Consciousness in Modern Japan. Stanford, CA: Stanford University Press.

Silverberg, Miriam

1991 The Modern Girl as Militant. In Recreating Japanese Women, 1600-1945. G. Bernstein, ed. pp. 239-266. Berkeley: University of California Press.

Stimpson, Catharine

1989[1974] The Androgyne and the Homosexual. In Where the Meanings Are: Feminism and Cultural Spaces. pp. 54-61. New York: Routledge.

Sugita Masaki

1929 Seihonnō ni hisomu sangyakusei. Kaizō, April:70-80.

1935 Shōjo kageki netsu no shinden. Fujin Kōron, April:274-278.

Tachibana Kyō

1890 Fūzoku hōtan. Fūzoku Gahō 14:15-16.

Takada Gi'ichirō

1926[1917] Hōigaku. Tokyo: Kasseido.

Takada Tamotsu

1934 Rebyū jidai kōsatsuki. Shinchō, March:57-64.

Takarazuka Gurafu

1977 Sensei to kataru. Takarazuka Gurafu 362:36-38.

1986 People: Ōura Mizuki. Takarazuka Gurafu 470:48-49.

Takarazuka Kagekidan

1990 Berusaiyu no bara. Takarazuka, Japan: Takarazuka Kagekidan.

Tamura Toshiko

1913 Dōsei no koi. Chūō Kōron, January:165-168.

Tanabe Seiko and Sasaki Keiko

1983 Yume no kashi o tabete: Waga itoshi no Takarazuka. Tokyo: Kōdansha.

Tomioka Masakata

1938 Dansei josō to josei dansō. Kaizō, October:98-105.

Tsuji Misako

1976 Niji no fuantajia. Tokyo: Shinromansha.

Ueda Yoshitsugu

1974 Takarazuka ongaku gakkō. Tokyo: Yomiuri Raifu. 
Ushijima Yoshitomo

1943 Joshi no shinri. Tokyo: Ganshodo.

Usumi Saijin

1935 Joryū sakka seikatsu ura omote. Hanashi, April:42-43.

Vance, Carole, ed.

1985 Pleasure and Danger: Exploring Female Sexuality. Boston: Routledge and Kegan Paul.

Vicinus, Martha

1989 Distance and Desire: English Boarding School Friendships, 1870-1920. In Hidden from History: Reclaiming the Gay and Lesbian Past. M. Duberman, M. Vicinus, and G. Chauncey, eds. pp. 212229. New York: New American Library.

Watanabe, Tetsuo, and Jun'ichi Iwata

1989[1987] The Love of the Samurai: A Thousand Years of Japanese Homosexuality. D. R. Roberts, trans. London: GMP.

Watashitachi no rekishi o tsuzuru kai, ed.

1987 Fujin zasshi kara mita 1930 nendai. Tokyo: Dōjidaisha.

Watson, Sophie, ed.

1990 Playing the State: Australian Feminist Interventions. New York: Verso.

Yabushita Tetsuji

1990 Yume o ikiru hitobito. Shingeki 442:106-113.

Yagi Kimiko

1989 Onna no fukusō. In Onna o yosou. Komashaku K., ed. pp. 80-115. Tokyo: Keiso Shobo.

Yamada Kōshi

1968 Rittaiteki ni miryoku o saguru. Takarazuka Gurafu 252:70-72.

Yashiki Kō

1935 "Dansō no reijin" no jogakusei jidai o kataru. Hanashi, April:250-256.

Yasuda Tokutarō

1935 Dōseiai no rekishikan. Chūō Kōron, March:146-152.

Yasui Shūhei

1953 Otoko ga onna ni, onna ga otoko ni dōshite nareta ka. Fujin Asahi, March:84-85.

Yoshida Genjirō

1935 Musume no ren'ai, dōseiại to haha. Fujin Kōron, March:156-160.

Yoshiwara Ryūko

1935 Gekkyū shōchōki ni aru musume o motsu okasama e. Fujin Köron, March:184-187.

Yoshizawa Jin

1966 Kō Nishiki no kako, genzai, mirai. Takarazuka Gurafu 229:51-53.

1967 Gō Chigusa no kako, genzai, mirai. Takarazuka Gurafu 236:69-71.

Yuri Yukiko

1985 Jendā. Asahi Shinbun (Tokyo evening ed.), 2 July.

\section{newspapers}

Asahi Shinbun. 13 January 1968, 21 December 1977, 3 December 1984, 29 March 1990.

English Mainichi. 22 February 1941.

Japan Times. 10 April 1990.

Ösaka Chōhō. 7 September 1940.

Ōsaka Jiji. 12 December 1934.

Ōsaka Mainichi. 29 May 1923, 10 February 1932, 15 January 1935, 31 January 1935.

Ōsaka Nichinichi. 21 July 1930, 20 August 1939.

Ōsakato. 15 July 1925, 17-20 July 1925, 22 July 1925.

Shin Nippō. 17 June 1936, 2 April 1940.

Yomiuri Shinbun. 23 May 1935.

submitted 6 August 1990

revised version submitted 19 April 1991

accepted 9 June 1991 